\title{
Reinvigorating Business Teacher Education towards Self-Reliance in Nigeria
}

\author{
Udoye, Nneka Rita \\ School of Business Education, \\ Federal College of Education (Technical) \\ Asaba-Delta State, Nigeria \\ Ndum, Victor Etim \\ Institute of Public Policy and Administration, \\ University Of Calabar, Nigeria
}

\section{Doi:10.5901/jesr.2013.v3n9p119}

\begin{abstract}
Any form of education that does not equip its beneficiaries with skills to be self-reliant is a faulty system of education. Business education must be ready to offer recipients functional education that will enhance performance as well as assist them to contribute meaningfully to the economic development of the country. This calls for education that will equip the students upon graduation to be fitted in the dynamic society. This includes the acquisition of skills in areas that will be useful to business students and make them self-reliant, independent and productive citizens of the society. Today the developments of Nigerian educational system and students' academic achievements have placed many demands on the effectiveness of business teachers. One of the demands is that schools should graduate students with employable skills. From an entrepreneurial perspective, the main aim of any business education is to improve the capability of the students to identify good business opportunities, evaluate these opportunities in terms of feasibility, and visualize a business model that can be commercialized. This paper examined the concepts of business education, business teacher education, self-reliance and dwelled extensively on modalities that could enhance business teacher education towards self-reliance. It is recommended among others that the curriculum developers should integrate those key areas that will help the students and 'would be' teachers to acquire necessary skills needed for sustenance of one's life and the society at large.
\end{abstract}

Keywords: reinvigorate, business education, business teacher education, self-reliance, curriculum.

\section{Introduction}

The basic aim of any business education is to improve the capability of the students to identify good business opportunities, evaluate these opportunities in terms of feasibility, and visualize a business model that can be commercialized (Thandi \& Sharma 2004). Such capability of potential entrepreneurs will improve their decision-making ability and conscious belief to bring about the desired results in performance, a phenomenon referred to as entrepreneurial self-efficacy (Bandura 1997).

The aim of entrepreneurship training as stipulated by the European Commission 2008, among others include; raising awareness of students about business skills, knowledge, promoting creativity, innovation and self-employment. This calls for entrepreneurship education that will equip the students upon graduation to be fitted in the dynamic society. This includes the acquisition of 
skills in areas that will be useful to business students and make them self-reliant, independent and productive citizens of the society (Ezeani, 2012).

Teboho (2000) revealed that the growth of our education industry is mainly in size and not in quality hence, the education system of Nigeria is yet to meet the challenges of preparing students for the contemporary global world. The quality of our education with its emphasis on theory more than practical has resulted in production of graduates with unemployable skills leading to unprecedented increase in different types of crimes in the country.

Teacher education which concern is the production of teachers at all levels has been recognized as major concern for the nation since no school whatever level, can be run without the teacher. Federal Government of Nigeria (2004) has it that teacher education will continue to be given a major emphasis in all our educational planning because no education can rise above the quality of its teachers. It becomes obvious that the wheel of education carried out by the teachers, norms, values, laws, artifacts and other societal upheld tenets can be passed on from one generation to another (Chukwurah, 2007).

According to Becker (1997), many business students find it difficult to apply economic principles after studying business concepts. It is therefore, imperative now to find ways and means of making the teaching and learning of the subject more effective. This paper examined the concepts of business education, business teacher education, self-reliance and dwelled extensively on modalities that could enhance business teacher education towards self-reliance in Nigeria.

\section{Conceptual Issues}

Today the developments of Nigerian educational system and students' academic achievements have placed many demands on the effectiveness of business teachers (Okolocha, and Onyeneke, 2013). Such assessment could initiate action that might lead to improvement especially now that there is public outcry about the quality of secondary school teachers and their inability to graduate students with employable skills.

Business studies form a means of laying foundation for national, technological, economical advancement and for higher education (N.P.E, 1981 revised in 2004) and (FRN, 2008). It equips its recipients with personal skills, consumer skills, and knowledge for clerical and managerial abilities needed to adapt to changing economic and business realities and these skills made them to be wealth and job creators rather than wealth and job seekers (Malik et al., 2010). Atakpa (2004) posited that it is that aspect of education that concern itself with vocational and professional preparation for career in business. Aliyu (2006) saw it as a comprehensive, practical and skill subjects while Ogben and Amahi (2008) maintained that business education equips students with knowledge and skills that will help them to find a job after schooling or create their own employment.

The teaching profession over a decade has been faced with many challenges in Nigeria with negative impact on the quality of education and the status of the Nigerian teachers. The most single critical element in the education process is the teacher who plans, organizes, designs, directs, motivates and inspires others to learn using standard teaching techniques to impart knowledge. Teaching according to Adeola (2011) citing Oyedeji (1998) is the process of imparting in the students' knowledge, skills and attitude in order to bring about a desirable change in learners. Interestingly, teachers are the hub of the educational system. Teachers are the most important factor in students learning next to students themselves. As a result, the pre-eminence of teachers, the application of pedagogical knowledge into classroom oriented plan of actions constitute most essential fabric upon which the success of the school, its administration and the entire education system rest upon. Education can change one's culture of learning, mind-set and orientation to values. Desirable transformation can only occur in the learner when a teacher has a good mastery of the subject matter, have a map to follow in terms of well-prepared lesson plan / note, grab the students' attention through effective class control mechanism or strategy, recognize 
student attention span, plan activity for the students by allowing students to participate actively in the teaching-learning encounter. The teacher should maintain approved lesson period, utilize visual aids, voice, eye contact and body movement as a way of stimulating the students, summarize lesson and evaluate lesson using all sorts of continuous assessment techniques.

\subsection{Business education}

Business education means many things to many people. Agwumezie (1999) saw business education as a programme in education that prepares students for entry into and advancement of jobs within the business. Aliyu (1999) considered it as a programme one needs to be proud of if properly designed, adequately prepared and religiously harmonized. Aliyu further affirms that business education is an educational programme which involves acquisition of skills, knowledge and competences which makes the recipient/beneficiary proficient. It is an umbrella under which all business programmes take a shield, such as marketing, business administration, secretarial studies and accounting.

To Igboke (2000:1), business education is a dynamic field of study geared towards preparing youths and adults for and about business. It is a preparation for a career in business when instruction is designed to prepare youths and adults for actual practice in the world of business. On the other hand, education about business involves preparation of youths and adults for intelligent and effective consumption of economic goods and services offered to society in our free enterprise economy.

However, business education will produce responsible, productive and self-reliant citizens. This highlights the importance of Business Education in inculcating in the recipients knowledge, values, attitudes and skills needed in the business world. Business education is an aspect of educational programme offered at the higher institution of learning which prepares students for careers in business.

Business education as a discipline is expected to expose its recipients to diversity curricula, hence, it is that type of education that inculcate in its recipients attitudes, knowledge, skills, values that is required in the business world. This is a means of producing a healthy, literate self-reliant citizen that would create wealth for human development, when they become self-employed, thereby resulting to sustainable nation's development at large

\subsection{Business teacher education}

The education of business teachers in Nigeria has been expanding and growing in recent years. This is as a result of increase in the demand for business teachers because of increase in students' enrolment in business education programme and quest for acquisition of employable skills both in private and public schools. In Nigeria's Third National Development Plan (1975 to 1980), the Federal Government maintained that the quality of teaching staff in all fields is probably the most important determinant of educational standards at all levels. Furthermore, the Federal Government of Nigeria (2004) stated that teachers' education will continue to be given a major emphasis in all our educational planning because no educational system can rise above the quality of its teachers. Therefore, for business education teacher quality to rise above the business education system, a strong global reform in business teacher education curriculum is required. Such reforms would enhance business teacher education the chance of being a component of any educational system charged with the education and training of teachers to acquire the competencies and skills of teaching for the attainment of self-reliance of the individual learner and the nation at large.

Ubulum (2000) looked at business teacher education as the pedagogical and business competencies necessary for teaching business attitudes, concepts, skills and knowledge. It could be seen as an aspect of educational training process which business teacher-trainees receive with the primary motive of enabling them acquire adequate attitudes, concepts, knowledge, understanding 
and skills in business activities, for personal or vocational usage, and/or for careers as administrators, managers and teachers wherever they may find themselves in the business world. Business teacher education aims at:

1. Educating business education teachers who will be positively oriented towards teaching business subjects.

2. Producing effective business teachers who are highly motivated and conscious of the important role they are expected to play in the development of business education.

3. Producing business teachers who possess sufficient knowledge in the theory and practice of business education which they can in turn teach in the teacher training colleges and

4. Equipping the business education students with sufficient knowledge and skills in business management.

However, business teacher education specially encompasses such programmes that are designed to give pedagogical training to those who will be engaged in the teaching of:

1. JSS Business studies;

2. Compartmentalized single business subjects at the senior secondary school (SSS), which includes; bookkeeping/ Accounts, Commerce, Economics, Typewriting and Shorthand; and

3. At the tertiary institutions/they are required to teach courses in Accounting, Business Management, Marketing, Computer Operation/Secretarial Studies, Methods of Teaching Business Education and other business related fields.

Business teacher education curriculum is structured in such a way that student-teachers are made to complete training in the four major components of teacher education which include:

a. General Education;

b. Professional (Pedagogical education);

c. Teaching subject; and

d. Teaching practice/students' industrial work experience (SIWES), NPE (2004).

\subsection{Self-reliance/entrepreneurship}

Entrepreneurship as a concept evolved many centuries ago and it has formed the basis for economic growth and development. It has been defined in different ways by various people. Entrepreneurship education refers to programmes that promote and provide skill training for business creation and development (Vesper, 1990). Entrepreneurship education is the type of education which has the ability to impact on the growth and development of an enterprise through technical and vocational training (Tamuo and Ogiji, 1999). To Atakpa (2011), it is the aspect of education which equips an individual and creates in the person the mindset to undertake the risk of venturing into something new by applying the knowledge and skills acquired in school. Still, to Fashua (2006), entrepreneurship education creates the willingness and ability in a person to seek out investment opportunities in the society and be able to establish and run an enterprise successfully based on the identified opportunities. This means that entrepreneurship education helps to provide business education students with the knowledge, skills and innovation to encourage entrepreneurship in variety settings.

In the light of this, Nigeria introduced several education policies such as the Universal Basic Education Scheme in Nigeria. This scheme was not only to fulfill and achieve the Education For All (EFA) target of 2015 as adopted by UNESCO but to produce self-reliant children who, according to one of the UBE objectives, are to be imparted with the rudiments of employment creating skills (entrepreneurship) at the junior secondary school level where technical and vocational (business education) education is emphasized (Federal Republic of Nigeria, 2004).

Entrepreneurship training in the Nigeria tertiary institutions was instituted by the Federal Government through the National Universities Commission (NUC) in 2006. This programme is aimed at equipping attitudes and competences in order to be job creators and not just hunters. The entrepreneurship training in the higher institution is geared towards assisting students to 
develop positive attitudes, innovative and skill towards self-reliance rather than depending on government to provide employment for them. (Banabo and Ndiomu, 2011). Nwangwu (2007) articulated the objectives of entrepreneurial education at the tertiary level to include:

- Providing graduates with adequate training that will enable them to be creative and innovative in identifying noble business opportunities.

- Providing functional education for youths so as to enable them to be self-employed and self-reliant.

- Providing graduates with adequate training in the acquisition of skills that will enable them to meet the manpower needs of the society.

However, it is considered that this will build up the confident in the business education students to engage in entrepreneurship venture after graduation.

\subsection{Business teacher education for self-reliance}

Business teacher education is not left out in the task of producing potential business teachers who would take up the challenges. Business educators play prominent roles in preparing students to become responsible citizens, capable of making astute economic decisions that would benefit their personal and professional lives. We witness changes continuously due to technological advancement globally and as such, business education programme becomes increasingly important for preparing learners to imbibe the changes.

The role of business education teachers as a handy tool in the realization of self-reliance in a country cannot be over-emphasized. Noting this important role, Ibigbami (2004) stressed that Business Teacher Education Curriculum should be developed in response to the national demand for education reform. Business teachers are therefore expected to demonstrate specific skills, apply knowledge and possess professional qualities which will enable them prepare students who can meet society's demands for high performance. The National policy on education (2004) in accordance with the existing Business teacher education programme provides for career development in business education at secondary school level to make it possible for recipients who cannot continue their education to the next level to find useful jobs. Business teacher education should exist with emphasis geared towards creating or offering employment opportunities covering a wide range of training requirements from certain semi-skilled sorting and filling jobs to managerial and executive positions (Ekpenyong, 2005).

The extent to which a curriculum assists business students and business teacher-trainees to competently enter and succeed in the world of work spells out success. In fact, every meaningful curriculum especially the business teacher education curriculum should not only be systematically developed, but should not be static or irrelevant. In terms of relevance, Wheeler in Chukwurah (2010) stated that business teacher education curriculum planning and development like every other education programme planning and development, is a continuous process and should be in the following phases:

1. The selection of aims, goals and objectives;

2. The selection of learning experiences calculated to help in the attainment of these aims, goals and objectives;

3. The selection of content (subject-matter) through which certain types of experiences may be offered;

4. The organization and integration of learning experiences and content with respect to the teaching/ learning process within the school and classroom; and

5. Evaluation of the effectiveness of all aspects of Phases- 2, 3 and 4 above in attaining the goals detailed in Phase one. These phases are related, interdependent and combined to form a cyclical process.

The following needs to be considered necessary for reforming business teacher education programme for self-reliance in Nigeria: 
i. Quality of candidates for business education programme: According to Federal Government of Nigeria, (2004), the Nigerian certificate of education (NCE) remains the minimum qualification for entry into teaching profession in the Nigeria educational system. Imogie (1999) considered such entry requirement in teaching to be too low to be regarded as a profession. Such poor entrants to the teacher education programme in our schools today constitute the problems of recruitment of competent and professionally trained business teachers into Nigerian school system (Afe, 2002). The poor quality of teachers according to Maxwell in Osho (1994) can be ascribed to the low entry behavior of preservice teachers.

ii. Training facilities for business teacher education programme: The importance of training facilities to the overall success of any educational enterprise has never been in doubt. It is on this basis that Olutola in Ekpenyong and Nwabuisi (2003) emphasized on the need for the provision of adequate training facilities. Chika (2000) maintained that training equipment and facilities needed for effective instruction of business education should be a replica of what is obtained and used in business offices and which the business teachertrainees must appreciate. Similarly, funding of tertiary institution in Nigeria is nothing to write home about and this invariably is affecting the procurement of required training equipment and facilities for business education teachers.

iii. It has been observed that some skills are likely to become obsolete as a result of lack of updating knowledge by business teachers. There is need for a workable staff development policy that would influence the retraining of business educators whose skills will turn out to be unmarketable. Such staff development will center on the area of new technology application. Business teachers need to engage themselves through a number of processes such as internet browsing, attendance to seminars, conferences, reading relevant books and journals and playing active roles in relevant professional associations.

iv. The need for the curriculum of business teacher education to be relevant to the needs of the student teachers cannot be overemphasized. Business teacher education curriculum should be viewed from the point of occupational and pedagogical competence, relevance to the needs of the students, society and employers, comprehension in scope, depth in knowledge and competence in skills, (Ojo, 2004).

\section{Conclusion}

It is a truism to indicate that teachers are the bedrock of students for academic performance, national growth and development. Teachers are the producers of individuals with critical skills for socio-economic development. They need to be effective in order to produce competitive knowledge workers for the global knowledge based economy. The role of business education teachers as a handy tool in the realization of self-reliance in a country cannot be over-emphasized.

\section{Recommendations}

The following recommendations are worthwhile:

- The education sector should be transformed by re-enforcing our teaching force. Qualified and dedicated business education teachers should be employed without being biased. This should be done by requesting the institution that graduate students to make input during teachers' selection stage.

- Enough funds should be budgeted for education and utilized judiciously without diverting it for selfish interest. Adequate funding of business teacher education should be a priority of governments and stakeholders.

- As business transactions are becoming more complex and computerized, government policy on computer education should provide for the training of business educators who 
will be well placed in training individuals for new jobs that are occasioned by automated equipment and devises;

- Appropriate legislation for the implementation of the National policy on teacher education is a necessity in Nigeria;

- For an effective enrichment of business teacher education curriculum, there is the need to develop a responsive curriculum which will be relevant to the current and anticipated needs, problems and aspirations of the learners.

\section{Refernces}

Adeola, L.K. (2011). An agreement of the teaching effectiveness of prevocational subjects in Ogun State, Nigeria. International Journal of Vocational and technical education, 3(1), 5-8.

Afe J.O. (2002). Thirty years of teacher education in Nigeria: A critical survey -Past, present and future, (ed) B. I paye, Lagos, Macmillan press.

Agbonife, B.A (1999). The business enterprise in Nigeria Lagos: Nigeria Plc

Agwumezie, F.U (1999). Resources management in business education programme:towards utilizing the great potentials of women. Business Education Journa/ 3(2) 128-136

Aliyu, M.A. (1999). Business education: relevance and functionality in Nigeria philosophy of education. Business Educational Journal, 3(2), 116-121

Atakpa, R. A. (2004). Improving professional standards in business education programmes in Nigeria: Issues and problems. Book of readings of Association of Business Educators of Nigeria, 1(4), 85-93.

Banabo, E., Ndiomu, K. (2011).Entrepreneurship and entrepreneur education: strategy for sustainable development. Asian J ournal for business Management Vol. 3. No 3.3.pp 196- 202

Bandura, A. (1997).Self-efficacy: The exercise of control, Freeman, New York.

Becker, W. (1997). Teaching economics to undergraduates. Journal of economics literature, 35 (3), $1347-1373$.

Chika MI (2000). Adequacy of instructional facilities and equipment for business Programme in Colleges of Education. Evidence from the Eastern States of Niger. Bus. Educ. J., 3(4).

Chukwurah CC (2007). Status of NCE business teachers education (BTE) programme in Cross River State, NASHER J ., 5(1).

Chukwurah CC (2010). Methodology in business and economic Education 1st Ed, Calabar: Mamy-O Koncept Publishers.

Ekpenyong L.E. (2005). Foundations of teachers and vocational education: new directions and approaches. Benin City, Nigeria: Supreme Ideal Publishers International Limited.

Ekpenyong, L.E, Nwabuisi J.N. (2003). Business teacher education in Nigeria: projecting a new direction. J. Voc. Educ. Train., 55(1).

Ezeani n. S. (2012). The teacher and skills acquisition at business Education: from the perspective of accounting skills. Arabian journal of business and management review (oman chapter) 2,(4).available:http://www.arabianjbmr.com/pdfs/om_vol_2_(4)/3.pdf.

Fashua, K.O. (2006). Enterpreneurship theory, strategies and practice. Abuja Bee.

FRN (2004). National Policy on Education. Lagos: NERDC Press

Honig, B 2004, „Entrepreneurship education: Toward a model of contingency-based business planning", Academy of Management Learning and Education, vol. 3, no. 3, pp. 258-273.

I gboke, S.A. (2000). Business education: principles and methods, Owerri: Cape Publishers International Ltd.

Kaegon, I.E.S. (2009). Enterpreneurship and education of youths for sustainable development in Nigerian tertiary institutions African Journal of educational research and development 3(2), 133-141

Nwangwu, I.G. (2007). Entrepreneurship in Education. Concepts and constraint. African Journal of Education and Development studies.4(1), 196-207

Ogben, F. \& Amahi, F.U. (2008). Business education in a globalized society: Issues, challenges and strategies. Business Education journal, 1(8), 37- 42

Ojo KE (2004). Strategies for the preparation of business teacher' education in the information and communication technology era in Nigeria. A paper presented at the 16th annual national 
conference of NABE held at the University of Calabar, 2-6th November.

Okoh, N. (1999). Business Education: Vision and m9ssion for sustainable economy: A keynote Address. Business Education Journal, 3(2), 1-8

Okolocha, C. C. Onyeneke, E.N.(2013). Secondary school principals' perception of business studies teachers' teaching effectiveness in Anambra state. Nigeria Journal of Education and Practice.4(2) 171

Osho I (1994). Business education in Nigeria: problems and prospects in studies in education. J. Fac. Educ. EDSU, Ekpoma, 2(1): 79-85

Peterman, N\& Kennedy, J 2003, „Enterprise education: influencing students" perceptions of entrepreneurship", Entrepreneurship Theory and Practice, vol. 28, no. 2, pp. 129-144.

Teboho, M. (2000). Nigeria education sector analytical synthesis of performance and main issues. New York

Thandi, H \& Sharma, R.( 2004)MBA student"s preparedness for entrepreneurial efforts“, Tertiary Education and Management, vol. 10, no. 3, pp. 209-226.

Ubulum WJ (2000): Business Education Curriculum for JSS: A guide for Practising Teachers, Celwil Nigeria Limited, Port Harcourt. 